\title{
NEW SPECIES OF OPECHONA LOOSS, 1907 AND CEPHALOLEPIDAPEDON YAMAGUTI, 1970 (DIGENEA: LEPOCREADIIDAE) FROM FISHES OFF NORTHERN TASMANIA
}

\author{
by Rodney A. Bray and Thomas H. Cribb
}

(with one text-figure)

BRAY, R.A. \& CRIBB, T.H., 2003 (19:xii): New species of Opechona Looss, 1907 and Cephalolepidapedon Yamaguti, 1970

(Digenea: Lepo-creadiidae) from fishes off northern Tasmania. Papers and Proceedings of the Royal Society of Tasmania 137: 1-5.

https://doi.org/10.26749/rstpp.137.1 ISSN 0080-4703. Department of Zoology, Natural History Museum, Cromwell Road, London SW7 5BD, UK (RAB*); Centre for Marine Studies and Department of Microbiology and Parasitology, University of Queensland, Brisbane, Queensland 4072, Australia (THC).

*Author for correspondence.

Two new species of lepocreadiid trematodes are described from teleost fishes from off the coast of northern Tasmania. Opechona kahawai sp. nov. from Arripis sp. (Arripidae) differs from congeners by a combination of a longer prepharynx, longer excretory vesicle and the genital pore antero-sinistral to the ventral sucker. Cephalolepidapedon warehou sp. nov. from Seriolella punctata (Centrolophidae) differs from its only congener in the vitellarium reaching into the posterior forebody, a heavy concentration of eye-spot pigment in the forebody, a relatively narrower and more elongate body, a longer prepharynx and a more distinct oesophagus.

Key Words: Opechona, Cephalolepidapedon, Arripis, Seriolella, Digenea, Lepocreadiidae, Tasmania.

\section{INTRODUCTION}

We have recovered two lepocreadiine species from the perciform fishes Arripis sp. (non georgiana) and Seriolella punctata (Forster, 1801) from the waters off northern Tasmania. According to records in the Host-Parasite database at the Parasitic Worms Division at the Natural History Museum, London, and a database produced at the Department of Microbiology and Parasitology, University of Queensland, neither species, indeed neither genus, has been reported as hosts of lepocreadiids before. Examination of these two forms has shown that they are undescribed and are, therefore, described as new.

\section{MATERIALS AND METHODS}

Digeneans collected from freshly-killed fish were fixed by being pipetted into nearly-boilingsaline and immediately preserved in formalin. Whole-mounts were stained with Mayer's haematoxylin, cleared in methyl salicylate and mounted in Canadabalsam. Measurements were made through a drawing tube on an Olympus BH-2 microscope, using a Digicad Plus digitising tablet and Carl Zeiss KS100 software adapted by Imaging Associates, and are quoted in micrometres as ranges and means in parentheses. Sucker-width ratio is given with the oral sucker width as one. The following abbreviations are used: BMNH, the British Museum (Natural History) collection at the Natural History Museum, London, UK; QM, Queensland Museum collection, Brisbane, Australia.

\section{RESULTS \\ Family Lepocreadiidae Odhner, 1905 Subfamily Lepocreadiinae Odhner, 1905 Genus Opechona Looss, 1907 Opechona kahawai sp. nov. \\ Fig. $1 A, B$}

\section{Type material}

Holotype: QM G221984, ex Arripis sp. (either trutta or truttacea) (Perciformes: Arripidae). Intestine. Off Stanley, Tasmania ( $40^{\circ} 46^{\prime} \mathrm{S}, 145^{\circ} 20^{\prime} \mathrm{E}$, Dec. 1999$)$.

Paratypes: QMG221985-221988, BMNH 2003.7.23.34-35, same data as holotype.

\section{Description}

Based on seven whole-mounts, four of which aremature. Body elongate, more or less parallel-sided, widest at oral sucker, bluntly rounded posteriorly, 3718-5307 × 315 × $473(4205$ $\times 359$ ); width $7.8-9.0$ (8.5)\% of length (fig. 1A). Tegument spinose; spines in regular rows, reach to close to posterior extremity; rows less regular close to posterior extremity. Eyespot pigmentscattered around posterior part of oral sucker and prepharynx. Oral sucker large, widely-flared funnel-shaped, terminal, 403-545 × 370-489 (451 × 411). Ventral sucker small, oval, pre-equatorial, on slight protuberance 125-147 $\times 124-157$ (132 × 136). Forebody 1599-2230 (1786) long, 40-44 (42)\% of length. Sucker-width ratio 1:0.32-0.36 (1: 0.33). Prepharynx distinct, 97-177 (134) long. Pharynx small, subglobular, 97-137 × 103-133 (111 × 119). Pharynx to oral sucker width ratio $1: 3.08-3.68(1: 3.46)$. Oesophagus lined with tegument, short, 11-42 (31) long. Pseudoesophagus (gastrodermis-lined) wider than oesophagus, 777-1068(877) long, 19-79 (37) times as long as oesophagus. Intestinal bifurcation just anterior to ventral sucker; anterior point of bifurcation 127-217 (162) from ventral sucker. Caeca narrow anteriorly, wider in post-testicular region, form uroproct at posterior extremity by opening into wide chamber at base of excretory vesicle. 


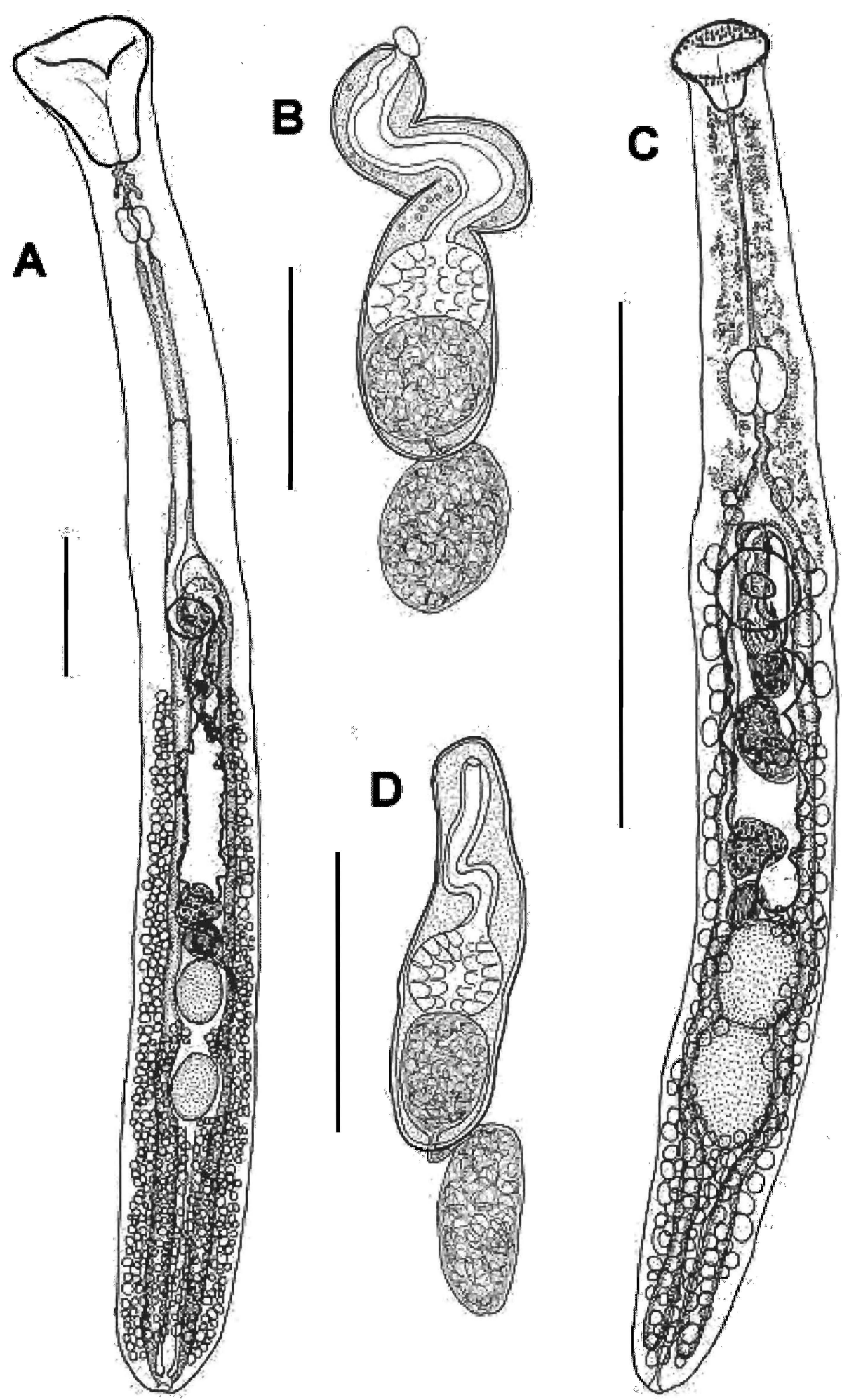

FIG. 1 - $(A, B)$ Opechona kahawai sp. nov. (A) Ventral view of holotype, uterus in bold outline, tiny tegumental spines not shown; (B) Cirrus-sac. (C,D) Cephalolepidapedon warehou sp. nov. (C) Ventral view of holotype, uterus in bold outline, tiny tegumental spines not shown; (D) Cirrus-sac. Scale-bars: A, C, $500 \mu \mathrm{m} ; \mathrm{B}, 200 \mu \mathrm{m} ; \mathrm{D}, 100 \mu \mathrm{m}$. 
Testes two, tandem, oval, entire, slightly to distinctly separated by 4-100 (43), in mid-hindbody; anterior $215-269 \times$ $167-200(241 \times 181)$, posterior $216-288 \times 172-203(252$ $\times 188$ ). Post-testicular region 686-1022 (799) long, 18-20 (19)\% of body-length. External seminal vesicle coiled, tubular, reaches 305-400 (340) into hindbody, 43-53 (51)\% of ventral sucker to ovary distance. Cirrus-sac of typical Opechona-type, claviform, convoluted, reaches well into hindbody, 365-500 × 108-127 (433 x 121) (fig. 1B). Internal seminal vesicle subglobular to oval. Pars prostatica vesicular, subglobular, lined with anuclear cell-like bodies, towards proximal end of cirrus-sac. Ejaculatory duct long, convoluted, muscular. Genital atrium distinct. Genital pore close to antero-sinistral margin of ventral sucker.

Ovary subglobular, virtually entire, but with evidence of three lobes separated by 69-111 (85) from anterior testis, median, $105-168 \times 114-170(137 \times 136)$; 573-924 (683) from ventral sucker. Seminal receptacle canalicular, saccular, mainly dorsal to ovary. Mehlis' gland dorsal to ovary. Laurer's canal opens dorsally to left caecum at about level of anterior margin of anterior testis. Uterus preovarian, intercaecal. Eggs not highly numerous, tanned, operculate, $75-87 \times 38-46(83 \times 41)$. Metraterm about half length of cirrus-sac; musculature develops gradually along length. Vitellarium follicular; fields reach into anterior hindbody, 75-191 (143) from ventral sucker; mainly lateral to caeca, encroach between testes, confluent dorsally and ventrally in post-testicular region.

Excretory pore terminal. Excretory vesicle I-shaped, initially a wide chamber at point where caeca join, then passes forward dorso-dextrally to testes, ovary and uterus, and reaches to mid-level of pseudoesophagus or slightly anterior; distal part lies ventrally to pseudoesophagus.

\section{Discussion}

Bray \& Gibson (1990) reviewed Opechona Looss, 1907 and related genera. Opechona was characterised within the Lepocreadiinae by the presence of a uroproct, a pseudoesophagus and a typical 'Opechona-type' cirrus-sac. They gave a key to those species that they considered definite members of the genus and also a key to those species which were possibly members of the genus, but which lacked some detail in the descriptions. In the first key our material from Arripis sp. comes closest to $O$. occidentalis Montgomery, 1957, an elongate form from scorpaenid fishes in the northeast Pacific Ocean. Opechona occidentalis differs in that the genital pore is at the posterior margin of the ventral sucker, the sucker ratio is much greater, the pseudoesophagus is only eight or nine times as long as the oesophagus and the excretory vesicle reaches only to the bifurcal level (Montgomery 1957). In addition, the eggs are larger in $O$. kahawai sp. nov. In the key to possible Opechona species, $O$. kahawai is closest to O. formiae Oshmarin, 1965 from formionids, stromateids and leiognathids in the northwest Pacific Ocean. In the latter species the caeca are figured as ending blindly, the sucker-ratio is distinctly greater, the prepharynx is longer and the genital pore is sinistro-lateral to the ventral sucker (Oshmarin 1965). Bray \& Cribb (1998) erected a further species of Opechona, O. austrobacillaris Bray \& Cribb, 1998 from Pomatomus saltatrix off both the eastern and western coasts of Australia. This is similar to $O$. kahawai, but differs in sucker-ratio (1:0.50-0.72) and in the pseudoesophagus being only 7-20 times the length of the oesophagus. Other species of Opechona erected since the review of Bray 8 Gibson (1990) are O. dongshanensis Wang \& Wang, 1993 from Upeneus sulphureus off China, O. gaevskayae Ahmad, 1991 from Fistularia villosain the Arabian Sea and O. glossoides Wang, 1989 from Megalaspis cordyla off China. A uroproct is not described in any of these species (Wang 1989, Ahmad 1991, Wang \& Wang 1993). Opechonis dongshanensis and $O$. glossoides also differ from $O$. kahawai in the anterior extent of the vitelline fields, which reach into the forebody in the former and reach to the ventral sucker in the latter. In $O$. gaevskayae the vitellarium is restricted to the hindbody, but the oral sucker is 'spherical' and the sucker ratio $1: 1$, the pseudoesophagus is only about three times longer than the pharynx and the excretory vesicle reaches only to the bifurcal level. Thus $O$. kahawai possesses a unique suite of characters which we believe justifies the erection of a new species.

\section{Etymology}

'Kahawai' is a common name of the host used in Australia and New Zealand (Froese \& Pauly 2003).

\section{Genus Cephalolepidapedon Yamaguti, 1970 Cephalolepidapedon warehou sp. nov.} Fig. 1C, D

\section{Type material}

Holotype: QM G221968. ex Seriolella punctata (Forster) (Perciformes: Centrolophidae). Intestine. Off Stanley, Tasmania (4046'S, $145^{\circ} 20^{\prime} \mathrm{E}$, Dec. 1999). Paratypes: QM G221969-221983, BMNH 2003.7.23.27-33, same data as holotype.

\section{Description}

Based on 23 whole-mounts. Body elongate, slightly wider in hindbody, rounded posteriorly, 994-1503 × 115-163 (1294 $\times 143$ ); width $9.5-14$ (11)\% of length (fig. 1C). Tegument spinose; spines in regular rows in forebody, sparse or absent in hindbody; anterior $2-3$ rows slightly, but distinctly, enlarged, appearing as tows of circum-oral spines. Eye-spot pigment copious, scattered throughout parenchyma of forebody and to about posterior margin of ventral sucker. Oral sucker funnel-shaped, with narrow posterior protuberance, terminal, $73-93 \times 79-98(83 \times 88)$. Ventral sucker small, rounded, pre-equatorial, on slight protuberance; 65-92 × 66-99 $(76 \times$ 78). Forebody 393-576 (481) long, 31-40 (37)\% of length. Sucker-width ratio 1:0.83-0.96 (1:0.89). Prepharynx long, 133-285 (196) long. Pharynx large, oval, 52-67 × 50-62 (60 $\times 55)$. Pharynx to oral sucker width ratio $1: 1.4-2.0(1: 1.6)$. Oesophagus lined with tegument, short, 18-119 (66) long. Intestinal bifurcation just anterior to ventral sucker; anterior point of bifurcation 47-104 (75) from ventral sucker. Caeca terminate blindly, 12-53 (35) from posterior extremity.

Testes two, tandem, oval, entire, contiguous or very slightly separated by $0-1.15(0.08)$, in mid-hindbody; anterior $64-136 \times 58-100(100 \times 83)$; posterior $75-167 \times$ 60-106 (119 × 88). Post-testicular region 200-269 (234) long, 16-21 (18)\% of body-length. External seminal vesicle saccular, reaches $107-258$ (154) into hindbody, $60-95(82) \%$ of ventral sucker to ovary distance; distal narrow, recurved duct reaches to cirrus-sac. Cirrus-sac of typical Opechona-type, claviform, convoluted, reaches into hindbody, $130-218 \times 34-54(181 \times 43)$ (fig. 1D). Internal seminal vesicle subglobular to oval. Pars prostatica vesicular, subglobular, lined with anuclear cell-like bodies, in proximal half of cirrus-sac. Ejaculatory duct long, convoluted, muscular. Genital atrium small. Genital pore antero-sinistral 
to ventral sucker.

Ovary subtriangular, contiguous or slightly separated by $0-45$ (23) from anterior testis, slightly dextral, 46-78 $\times 40-72(62 \times 58) ; 125-299$ (189) from ventral sucker. Ventral sucker to ovary distance 11-21 (15)\% of bodylength. Seminal receptacle canalicular, saccular, in dorsal plane between ovary and anterior testis or dorsal between junction of them. Mehlis' gland dorsal to ovary. Laurer's canal opens dorsally to left caecum or sinistral edge of anterior testis, at about level of anterior third of anterior testis. Uterus pre-ovarian, mainly intercaecal. Eggs relatively few (c. 3-19), tanned, operculate, $52-63 \times 27-37(58 \times 32)$. Metraterm distinct, muscular, reaches from about posterior edge of ventral sucker. Vitellarium follicular; fields reach into posterior forebody, 29-124 (74) from ventral sucker; mainly lateral to caeca; in ventral plane scattered follicles may overlie uterus, encroach over testes slightly and be confluent ventrally in post-testicular region; in dorsal plane follicles encroach caeca only slightly at level of gonads and fields are separated by excretory vesicle in post-testicular region.

Excretory pore terminal. Excretory vesicle I-shaped, narrow, reaches to anterior part of post-testicular region or just overlaps posterior testis.

\section{Discussion}

The general morphology of the type, and only, species of Cephalolepidapedon, C. saba Yamaguti, 1970, is similar to other lepocreadiines, but differs from most by the rows of slightly-enlarged spines around the aperture of the oral sucker. These are not greatly enlarged, as is found, for example, in the acanthocolpid genera Stephanostomum Looss, 1899 or Stephanostomoides Mamaev \& Oshmarin, 1966, or other lepocreadiids, such as Acanthogalea Gibson, 1976, but are similar to those of Clavogalea Bray, 1985. Cephalolepidapedon is distinguished from Clavogalea by its blind-ending caeca and lack of a pseudoesophagus, although the pseudoesophagus in Clavogalea may be insignificant, as in the type-species C. gaevskayae Bray, 1985 (Bray \& Gibson 1990) or much longer than the oesophagus, as in C. trachinoti (Fischthal \& Thomas, 1968) (see Bray \& Cribb 1998). Yamaguti (1970) described $C . s a b a$ as having a long excretory vesicle reaching to the pharynx, but examination of the 'type-series' and new material by Shimazu (I989) has shown it to be short, "barely reaching to posterior testis'. The specimens described here are considered members of Cephalolepidapedon because they have the following suite of characters: slightly-enlarged oral spines, blind caeca, lack of a pseudoesophagus, short excretory vesicle and funnel-shaped oral sucker.

Cephalolepidapedon saba (syns Stephanostomum tristephanum of Zhukov (1960); S. scombri Korotaeva, 1974; Opechona acanthoris Gaevskaya \& Aleshkina, 1985; Lepocreadium misakiensis Shimazu, 1986) has been found in two species of Scomber, but from a geographically wide area, that is, $S$. [ = Pneumatophorus $]$ japonicus off Hawaii (Yamaguti 1970), in the Sea of Japan (Shimazu 1986; Shimazu 1989; Zhukov 1960), in the East China Sea (Shen 1986), in the Yellow and Bo Hai seas (Shen \& Qiu 1995) and in the southeastern Atlantic (Gaevskaya \& Aleshkina 1985), and in S. australasicus from the Great Australian Bight (Korotaeva 1974). The species has also been reported from off Hainan Island in the South China Sea, but the host is not given (Shen \& Li 2000). The species has been described several times (Zhukov 1960; Yamaguti 1970; Korotaeva 1974; Gaevskaya \& Aleshkina 1985; Shimazu 1986; Shimazu 1989; Shen \& Qiu 1995). Cephalolepidapedon warehou sp. nov, is morphologically similar to $C$. saba, but can be distinguished by the vitellarium reaching into the posterior forebody, the heavy concentration of eye-spot pigment in the forebody, a relatively narrower and more elongate body, a longer prepharynx and a more distinct oesophagus. In $C$. $s a b a$ the vitellarium is restricted to the hindbody, reaching anteriorly only as far as the middle of the ventral sucker to ovary distance. The illustrations in Zhukov (1960), Yamaguti (1970) and Shimazu (1986) show scattered eyespot pigment, but it is much less widely distributed than in $C$. warehou, being confined to the area between the oral sucker and the pharynx.

\section{Etymology}

Silver or Spotted 'Warehou' are common names of the host used in Australia and New Zealand (Froese \& Pauly 2003).

\section{ACKNOWLEDGEMENTS}

We are grateful to Sylvie Pichelin for helping THC in the collection of this material and Trudy Wright for processing the material. David Gibson kindly read the manuscript.

\section{REFERENCES}

AhMAD, J., 1991: A new genus and three new species of digenetic trematodes from marine fishes of Arabian Sea. Pakistan Journal of Zoology 23: 99-104.

BraY, R.A. \& CRiBb, T.H., 1998: Lepocreadiidae (Digenea) of Australian coastal fishes: new species of Opechona Looss, 1907, Lepotrema Ozaki, 1932 and Bianium Stunkard, 1930 and comments on other species reported for the first time or poorly known in Australian waters. Systematic Parasitology 41: 123-148.

BRAY, R.A. \& GIBSON, D.I., 1990: The Lepocreadiidae (Digenea) of fishes of the north-east Atlantic: review of the genera Opechona Looss, 1907 and Prodistomum Linton, 1910. Systematic Parasitology 15: 159-202.

Froese, R \& Pauly, D., 2003: Fishbase. World Wide Web electronic publication: www.fishbase.org.

Gaevskaya, A.V. \& Aleshrina, L.D., 1985: New species of trematodes from the eastern Atlantic. Parazitologiya 19: 105-112. (In Russian.)

KorotaEva, V.D., 1974: [Helminths of some commercial marine fish of the sub-order Scomberoidei from the Australian region]. Izvestiya Tikhookeanskogo Nauchno Issledovatel'skogo Instituta Rybnogo Khozyaistva i Okeanografii (TINRO) 88: 61-66.

MONTGOMERY, W.R., 1957: Studies on digenetic trematodes from marine fishes of La Jolla, California. Transactions of the American Microscopical Society 76: 13-36.

OSHMARIN, P.G., 1965: [On the trematode fauna of marine and freshwater fishes of Vietnam.] In Leonov, A.A., Mamaev, Y.L. \& Oshmarin, P.G. (Eds): Parasitic worms of domestic and wild animals. Akademiya Nauk SSSR, Vladivostok: 213-249. (In Russian.)

SHEN J., 1986: Digenetic trematodes of fishes from the east China Sea I. Species of the families Opistholebetidae, Lepocreadiidae and Cryptogonimidae. Studia Marina Sinica 27: 209-219.

SHEN J.-W. \& LI X.-H., 2000: Addendum to the parasite digenetic trematodes from marine fishes in Hainan Island. Studia Marina Sinica 42: 153-162. (In Chinese.)

SHEN J.-W. \& QIU Z.-Z., 1995: Studies on the trematodes of fishes from the Yellow Sea and the Bo Hai Sea. Science Press, 
Beijing, 207pp. (In Chinese.)

SHIMAZU, T., 1986: Lepocreadium misakiense sp. $n$. and Neopechona olssoni (Yamaguti, 1934), comb. n. (Trematoda: Lepocreadiidae), parasites of a Japanese marine fish, Scomber japonicus. Zoological Science 3: 569-571.

SHimazu, T., 1989: Taxonomic notes on Cephalolepidapedon saba and Opechona orientalis (Trematoda: Lepocreadiidae) of the marine fish, Scomber japonicus (Teleostei: Scombridae). Japanese Journal of Parasitology 38: 232-235.

WANG P.-Q., 1989: Digenetic trematodes of marine fishes in Pingtan County, Fujian Province, South China. Wuyi Science Journal 7: 151-163. (In Chinese.)

WANG P.-Q. \& WANG Y.-Y., 1993: Some digenetic trematodes of marine fishes from Fujian Province. Journal of Fujian Normal University, Natural Science 9: 66-73. (In Chinese.)

Yamaguti, S., 1970: Digenetic trematodes of Hawaiian fishes. Keigaku Publishing Co., Tokyo, 436 pp.

Zhukov, E.V., 1960: Endoparasitic worms of the fishes in the Sea of Japan and South-Kuril shallow-waters. Trudy Zoologicheskogo Instituta, Leningrad 28: 3-146. (In Russian.)

(accepted 28 July 2003) 